\title{
INCIDENCE OF ROOT (WILT) DISEASE IN VARIOUS CROSS COMBINATIONS OF WEST COAST TALL VARIETY OF COCONUT
}

BY

\author{
R.V. Nair ${ }^{1 /}$, P.M. Jacob ${ }^{2 /}$, M.G. Rajesh ${ }^{1 /}$ and R.J. Thomas ${ }^{1 /}$
}

\begin{abstract}
Root (wilt) disease is a very serious disease of coconut in eight southern districts of Kerala, India. A comprehensive breeding programme - the only practical solution for the management of the disease - was started at Central Plantation Crops Research Institute (CPCRI), Kayangulam during 1987. Coconut seedlings, belonging to five cross combinations with WCT viz. WCT (Inter se), West Coast Tall (WCT) (Self), WCT (Mixed Pollen), Chowghat Green Dwarf (CGD) $x$ WCT and WCT (Open Pollinated) were studied for their incidence of root (wilt) disease. All the seedlings were planted during 1992 except CGD $x$ WCT which was planted during 1991. In the absence of a mass screening technique under artificial conditions, assessment of resistance was based on natural infection. The progenies belonging to various cross combinations of WCT $x$ WCT showed significant variability for incidence of root (wilt) disease. Observations, recorded during September 2002 , revealed that the incidence of root (wilt) varied from 53.4 to $55.2 \%$ in WCT $x$ WCT crosses whereas CGD $x$ WCT had $64.5 \%$. Open pollinated seedlings from healthy mother palms contracted $70 \%$ incidence of the disease. The studies showed superiority of artificially pollinated seedlings (full sibs) over the open pollinated seedlings (half sibs) with regard to their susceptibility to the disease.
\end{abstract}

$1 /$ Central Plantation Crops Research Institute (Regional Station), Kayangulam, Kerala, India.

2/ Presently Head, CPCRI (Regional Station), Minicoy, Lakshadweep - 682559 , India 


\section{INTRODUCTION}

Root (wilt) is a serious disease of coconut in Kerala and also in certain districts of Tamilnadu (Srinivasan et. al., 2000). According to the survey conducted during 1984, the disease causes an annual loss of 968 million nuts (Anon., 1985). In the contiguously diseased area, vast majority of palms have succumbed to the disease (Anon.,1996).

Flaccidity, yellowing and necrosis of leaflets, are the major distinguishing symptoms of the disease. Systematic investigations carried out at CPCRI (RS), Kayangulam on the etiology of the disease suggested the association of phytoplasma (Solomon et. al., 1983a), transmitted through Stephanitis typica (lace bug) (Mathen et. al., 1987) and Proutista moesta (plant hopper) (Anon., 1991). Earlier studies have revealed that out of the 63 cultivars and 32 hybrid combinations screened for resistance under field conditions, none of them had the desired level of resistance (Solomon et. al., 1999).

Mass screening technique for systematic evaluation of resistance under artificial conditions to coconut root (wilt) disease has not been developed so far. It was observed that in the disease endemic areas of Kottayam, Alappuzha, Kollam and Pathanamthitta districts, in the midst of heavily disease affected palms, disease-free and high yielding West Coast Tall (WCT) palms were found and these palms are identified as the base material for the production of quality planting materials. Studies based on screening trial and survey of natural population indicated that typical Chowghat Green Dwarf (CGD) palms are having higher level of resistance to the disease when compared to the other varieties (Nair et. al., 1999).

A comprehensive breeding programme for resistance / tolerance to coconut root (wilt) disease is being implemented (Nair et.al. 1996). This study assumes considerable significance, as it is the first report of its kind on the disease resistance of progenies belonging to various cross combinations of West Coast Tall variety produced from the diseased area.

\section{MATERIALS AND METHODS}

Parental palms located in farmers' plots in the hot spot areas were selected for crossing based on the following selection criteria.

\section{(i). West Coast Tall (WCT):}

a. Parental palms should yield 80 or more nuts per palm per year.

b. Palms should be regular bearers and absolutely free from all diseases and pests.

c. Palms should be more than 35 years old and surrounded by palms of which at least $80 \%$ are affected by the root (wilt) disease, in an endemic area. 
d. Tall mother palms should have typical WCT characters. Twenty-five open pollinated seedlings are grown from each mother palm and all progeny seedlings should show uniform vigour and colour characters of WCT. This progeny test is done to cull out hybrid mother palms, if any.

e. Palms should be negative in their reaction to the root (wilt) antiserum and the serological tests (Solomon et. al., 1983b) are to be repeated every year.

\section{(ii). Chowghat Green Dwarf (CGD):}

a. Palms should preferably yield 80 nuts or more per year.

b. Palms should be preferably healthy and free from all diseases and pests.

c. Parental palms should be above 20 years of age and surrounded by palms of which at least $80 \%$ are affected by the root (wilt) disease, in an endemic area.

d. Palms should show typical CGD characters with regard to stem, crown, leaf and nut.

e. Palms should be negative in their reaction to the root (wilt) antiserum and the serological tests (Solomon et. al., 1983b) are to be repeated every year.

Artificial pollination of mother palms were carried out in the farmers' plots, located in the hot spot areas, following the standard procedure of Pillai and Rao (1984).

The following crosses were carried out for the production of progenies.

\section{WCT (Inter se) \\ 2. WCT (Self) \\ 3. WCT (Mixed Pollen) \\ 4. CGD X WCT \\ 5. WCT (Open Pollinated)}

The mature nuts of various cross combinations were harvested after 10 to 12 months of pollination and sown in the nursery.

In the absence of a mass screening technique for evaluation of resistance under artificial conditions, screening was done under natural conditions since this disease occur in epidemic proportions in the diseased tract. One year old seedlings of the above cross combinations were underplanted in the normal spacing of $7.5 \mathrm{~m}$ x $7.5 \mathrm{~m}$ at CPCRI (Regional Station), Kayangulam where heavy natural incidence of the disease is prevalent. Seedlings were managed by following the recommended cultural practices (Amma et. al., 1982). Old diseased palms were retained in the same field at least for ten years after under planting of the seedlings, to provide sufficient inoculam for natural infection under field conditions. All the seedlings were planted during 1992 except CGD X WCT, which was planted during 1991. Seedlings, as and when they contracted root (wilt) 
disease were removed and replanted in the same pit with another test seedling for evaluation of field resistance. This method facilitates to save space and allow testing of more palms for field resistance.

Observations were recorded as and when the experimental seedlings developed initial symptoms of the disease.

\section{RESULTS AND DISCUSSION}

The compiled data on the incidence of root (wilt) disease for 10 years after planting is given in Table 1. Observations on CGD x WCT hybrids planted during 1991 indicated that 20 palms out of the 31 planted showed symptoms of the disease $(64.5 \%)$ indicating their susceptibility to the disease. The hybrids came to flowering in $40-50$ months after planting and gave a cumulative average yield of 82 nuts per palm till 2001 i.e. ten years after planting. This indicated that CGD $X$ WCT hybrids inspite of their susceptible nature are promising for their yield.

Incidence of the disease in the artificially pollinated seedlings of WCT (WCT Inter se / Self / Mixed Pollen) varied from 53.4 to $55.2 \%$, whereas in the case of open pollinated seedlings of WCT, there was 70 per cent disease incidence. This showed the superiority $(15 \%)$ of the artificially pollinated seedlings (full sibs) over the open pollinated seedlings (half sibs) with regard to their resistance to the disease.
All the palms that have contracted root (wilt) disease in the young stage were removed based on the observations that yield is drastically reduced when palms contract root (wilt) disease at the young stage (Mathew et. al., 1993). Therefore yield data of all such palms which have contracted root (wilt) disease at the young stage are not available. Most of the remaining palms, planted during 1992 are either in the flowering stage or in the immature phase of fruiting (before the stabilized stage of yield). Therefore it will be too early to assess their performance for yield.

The above results on incidence of the disease point to the possibility of resistance being governed by recessive genes because of the following facts. (i) There is a preponderance of susceptible palms when compared to disease-free palms in the natural population. (ii) In the segregating population also, almost half of the population contract root (wilt) disease in the juvenile phase itself.

Farmers in the root (wilt) tract traditionally collect open pollinated nuts from high yielding mother palms to raise seedlings for their planting requirement. Incidence of coconut root (wilt) disease in cross combinations involving WCT and also in open pollinated progenies has not been reported earlier and this information is valuable not only to plant breeders but also to farmers. 


\section{ACKNOWLEDGEMENT}

The authors wish to thank Dr. V.Rajagopal, Director, CPCRI, Kasaragod for facilities, Dr. J.J.Solomon, Acting Head, CPCRI, Regional Station, Kayangulam and Dr. P.M. Kumaran, Acting Head, Division of Crop Improvement for suggestions.

\section{REFERENCES}

1. Amma, P.G.K., Cecil, S.R., Pillai, N.G., Mathew A.S. and Nambiar, P.T.N.1982. Performance of Dwarf X Tall hybrid coconut in root (wilt) affected areas of Kerala under different fertilizer levels. In: Bavappa, K.V.A.et.al.(Eds.)Proc. PLACROSYM V. CPCRI, Kasaragod, 15-18 Dec. 1982. PLACROSYM standing committee. pp 405-410.

2. Anonymous. 1985. A survey Report. Coconut root (wilt) disease-Intensity, production loss and future strategy. Central Plantation Crops Research Institute, Kasaragod, Kerala 671 124, India. pp. 45.

3. Anonymous. 1991. Annual Report for 1990-91, Central Plantation Crops Research Institute, Kasaragod, Kerala 671 124, India. pp. 154.

4. Anonymous. 1996. Coconut Root (Wilt) Survey. Department of Agriculture. Government of Kerala. pp. 22

5. Mathen, K., Solomon, J.J., Rajan, P and Geetha, L. 1987. Electron microscopic evidence on the Stephanitis typica (Distant) as the vector of coconut root (wilt). Curr. Sci. 56(23): 1239-1240.

6. Mathew, J., Cecil, S.R., Amma, P.G.K. and Pillai, N.G. 1993. Impact of root (wilt) disease on the yield of young coconut palm. In: Advances in Coconut Research and Development (Eds.) Nair et. al., Oxford and IBH Publishing Co. Pvt. Ltd. pp. 605-615

7. Nair, M.K., Koshy, P.K., Jacob, P.M., Rao, E.V.V.B., Nampoothiri, K.U.K. and Iyer, R.D. 1996. A root (wilt) resistant coconut hybrid and strategy for resistance breeding. Indian Coconut J. 27(1): 2-5.

8. Nair, R.V., Jacob P.M. and Ajith Kumar. 1999. Screening of coconut varieties against root (wilt) disease. Indian Phytopath. 53(3): 369 (Abstract No.11)

9. Pillai, R.V. and Rao, E.V.V.B. 1984. Technique for commercial production of coconut hybrids. Extension pamphlet no.18. Central Plantation Crops Research Institute, Kasaragod, Kerala, India. 10p.

10. Solomon, J.J., Govindankutty, M.P. and Nieuhaus, F. 1983a. Association of mycoplasma - like organisms with the coconut root (wilt) disease in India. Z. Pflkrankh. Pflschutz. 90: 295297

11. Solomon, J.J., Nair, C.P.R., Srinivasan, N., Gunasekaran, M and Sasikala, M. 1999. Coconut root (wilt)- The Malady and Remedy. $J$. Plantn. Crops. 27(2): 71-92.

12. Solomon, J.J., Sasikala, M. and Shanta, P. 1983b. A serological test for the detection of root (wilt) disease of coconut. In: Coconut Research and Development (ed. N.M. Nayar) Wiley Eastern Ltd., New Delhi. pp. 401-405.

13. Srinivasan, N., Koshy, P.K., Kamalakshy Amma, P.G., Sasikala, M., Gunasekaran, $M$ and Solomon, J.J. 2000. Appraisal of the distribution of coconut root wilt and heavy incidence of the disease in Cumbum Valley of Tamil Nadu. Indian Coconut J., 31(1): 1-5. 
Table 1. Incidence of coconut root (wilt) disease in various cross combinations of West Coast Tall

\begin{tabular}{|c|c|c|c|c|c|}
\hline \multirow{2}{*}{$\begin{array}{l}\text { Sl. } \\
\text { No. }\end{array}$} & \multirow[t]{2}{*}{ Cross Combination } & \multirow{2}{*}{$\begin{array}{l}\text { Year of } \\
\text { Planting }\end{array}$} & \multirow{2}{*}{$\begin{array}{c}\text { No. of } \\
\text { plants } \\
\text { observed }\end{array}$} & \multirow{2}{*}{\begin{tabular}{|c|}
$\begin{array}{c}\text { No. of plants } \\
\text { diseased }\end{array}$ \\
September/02
\end{tabular}} & \multirow{2}{*}{$\begin{array}{c}\begin{array}{c}\text { Percentage of } \\
\text { disease } \\
\text { incidence }\end{array} \\
\text { September/02 }\end{array}$} \\
\hline & & & & & \\
\hline 1. & CGD X WCT & 1991 & 31 & 20 & 64.5 \\
\hline 2. & WCT (Inter se) & 1992 & 105 & 48 & 55.2 \\
\hline 3. & WCT (Self) & 1992 & 37 & 21 & 55.3 \\
\hline 4. & WCT (MP) & 1992 & 118 & 63 & 53.4 \\
\hline 5. & WCT (OP) & 1992 & 20 & 14 & 70.0 \\
\hline \multicolumn{3}{|c|}{ Total } & 311 & 166 & 59.68 \\
\hline
\end{tabular}

CGD - Chowghat Green Dwarf

WCT - West Coast Tall MP - Mixed Pollen

OP - Open Pollinated 